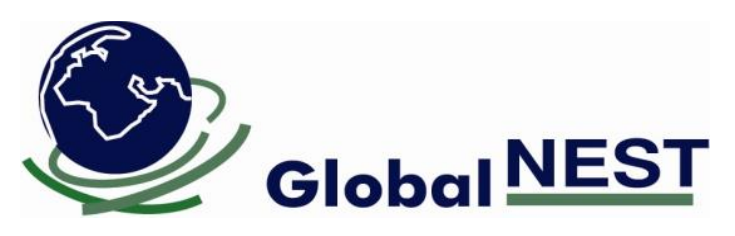

\title{
LIMESTONE PARTICLE ATTRITION AND SIZE DISTRIBUTION IN A BENCH SCALE BUBBLING FLUIDIZED BED
}

\author{
YANG Z.Q.. \\ REN W.G. \\ ZHANG L. \\ QIAN C.R. \\ YAN Y.Y. \\ GUO M.N.
}

Received: $12 / 06 / 2014$

Accepted: 09/12/2014

Available online: 27/02/2015
Key Laboratory of Low-grade Energy Utilization Technologies and Systems Chongqing University, Ministry of Education of PRC

Shapingba Dist. Chongqing, 400030, P.R.China

\begin{abstract}
Attrition of limestone particles in bubbling fluidized bed has significant influence on cyclic $\mathrm{CO}_{2}$ capture ability of sorbents. The limestone particle attrition and size distribution characteristics were investigated experimentally in a bench scale fluidized bed. The effects of initial particle sizes, fluidized velocity, attrition time and temperature on limestone attrition characteristics were studied. An empirical fitting correlation was proposed to describe the relationship of cumulative mass fraction of limestone fines $(R)$ and attrition time $(t)$. The results show that the fines generation rate decreases and particle size reduction rate increases with increasing initial size. Chipping of large particle takes predominant position when fluidized velocity exceeds the minimum fluidization velocity resulting in more prominent reduction of particle size. After 4 hours attrition, particle size reduction and fines generation rate become constant. It is suggested that cumulative mass fraction of limestone fines $(R)$ increases with attrition time with a function of decaying exponential correlation.
\end{abstract}

Keywords: limestone attrition; particle size distribution; particle reduction; decay rate

\section{Introduction}

During the past few decades, it has been widely accepted that $\mathrm{CO}_{2}$ emission produced by power plants, heating systems, internal combustion engines, and other energy-consuming processes have increased rapidly, contributing to the greenhouse gas effect which was considered to be the main factor of climate change. According to statistics, the $\mathrm{CO}_{2}$ emission produced by power plants system takes one third of the gross of human-related $\mathrm{CO}_{2}$ emission in nature. It is very likely that absolute zero $\mathrm{CO}_{2}$ emission will become compulsory restriction on energy and heat related systems in the future just like the regulation of $\mathrm{SO}_{2}$ and $\mathrm{NO}_{x}$. In parallel with the development of technologies which utilize non-carbon-based energy sources, releasing $\mathrm{CO}_{2}$ after capturing and sequestering them with sorbent offers possible effective means of reducing the emission of greenhouse gases (Chen et al., 2009, Li et al., 2011). Obviously, it is quite significant to choose appropriate natural materials with rich reserves and easy acquiring as $\mathrm{CO}_{2}$ sorbent for cost reduction and energy saving. The reversible reaction of $\mathrm{CaO}$ and $\mathrm{CO}_{2}$ provides calcium oxide great potential to become clean

Yang Z.Q., Ren W.G., Zhang L., Qian C.R., Yan Y.Y. and Guo M.N. (2015), Limestone particle attrition and size distribution in a bench scale bubbling fluidized bed, Global NEST Journal, 17(2), 236-247. 
and economical sorbent which can be widely applied in power industry with now available technology (Park et al., 2006). Natural limestone with its advantage in plentiful supply, high cost-effective and good performance becomes one of major sorbents for $\mathrm{CO}_{2}$ capture with carbonation/calcination cyclic reaction method (Coppola et al., 2012).

During $\mathrm{CO}_{2}$ capture in fluidized bed reactor with limestone as sorbent, particle attrition is widely concerned (Cook et al., 1996; Blamey et al., 2010). Attrition occurs among particles and also between limestone particles and walls. Breakage and chipping of particles due to collision with a hard surface are common occurrence in many conveying and handling systems including fluidized bed reactors. Chipping and fines produced by attrition pollute the environment and even cause dust explosion. Furthermore, attrition brings unstable factors to system because of collision and erosion weakening internal surface of system. Many researchers investigated attrition mechanism of calcium based absorbent particles in reversible reactions. Ghadiria (2002) and Jia et al., (2007), proposed that two aspects of factors, known as properties of limestone and experimental system, had an influence on attrition. The properties of particles such as initial sizes, surface, porosity, hardness, cracks, density, shape, and particle strength strongly affect the attrition. Operating conditions such as fluidized velocity, temperature and attrition time played important roles in attrition performance. Attrition caused by abrasion and chipping are two major behaviors at room temperature in a relative low velocity (Chirone et al., 1991). Surface attrition is determined by small debris and fines produced by abrasion. Coppola et al., (2012) studied limestone attrition processes by measuring the changes of the sorbent particle size distribution and the fines elutriation rate along conversion over repeated cycles. They found that moderate attrition rates were experienced by sorbent particles mostly during the first cycle. And attrition rate decreased with number of cycles, and only moderately affected by presence of $\mathrm{SO}_{2}$. Chen et al., (2007) proposed a model to predict the particle size distribution for batch impact attrition. Xiao et al. (2011) found that there was a linear relation between particles average size and attrition time based on long term tests at room temperature. Current researches mainly focused on limestone particle integral attrition (González et al., 2010). Mechanism of abrasion and chipping on different attrition stages should be further studied (Lee et al., 1993; Scala et al., 1997; Salman et al., 2002; Ray et al., 1987).

In this paper, long term attrition experiments were conducted to study contribution of abrasion and chipping on limestone particles attrition. The effects of particle initial size, fluidized velocity and time on particle attrition were investigated. An empirical fitting correlation for cumulative mass fraction of limestone fines $(R)$ and time was proposed based on our study.

\section{Experimental Section}

\subsection{Experimental Details}

The experimental system of a bench scale bubbling fluidized bed is shown in Fig. 1. A 1200-mm-long stainless steel $(0 \mathrm{Cr} 25 \mathrm{Ni20})$ tube with $65 \mathrm{~mm}$ inner diameter was employed as fluidized section. Before each attrition test, $100 \mathrm{~g}$ of limestone particles were sieved and weighed to determine their original particle size distribution and mean particle diameter. For the high-temperature tests, the air was pre-heated to the desired temperature by the preheater and electrical heater. The particles were then loaded through the feeding port. The open porosity of the distributor was $0.71 \%$. A fiber bag was connected to end of export pipe, and fines were trapped in the collector. After operating the bubbling fluidized bed continuous limestone attrition apparatus for a pre-determined period, the heating and air feed were terminated. When cooled down, all particles at the bottom of the bubbling fluidized bed collected were sieved and weighed.

Yubei limestone was employed to conduct the attrition experiments. The elemental analysis results of Yubei limestone were shown in Table 1. Tests reported in this paper were carried out with air as fluidized gas from room temperature (about $25^{\circ} \mathrm{C}$ to $1000{ }^{\circ} \mathrm{C}$ and $1 \mathrm{~atm}$ pressure. The raw limestone particles were divided into 
several size intervals by sieving. A limestone sample $(100 \pm 0.1 \mathrm{~g})$ was feed from the top of fluidized bed reactor for each experiment. The flow rate was adjusted to $7.6^{\sim} 15.3 \mathrm{~m}^{3} \mathrm{~h}^{-1}$ to study the effect of fluidized velocity on attrition. After the attrition tests $(0 \sim 8 \mathrm{~h})$, particles and fines are carefully collected and sieved.

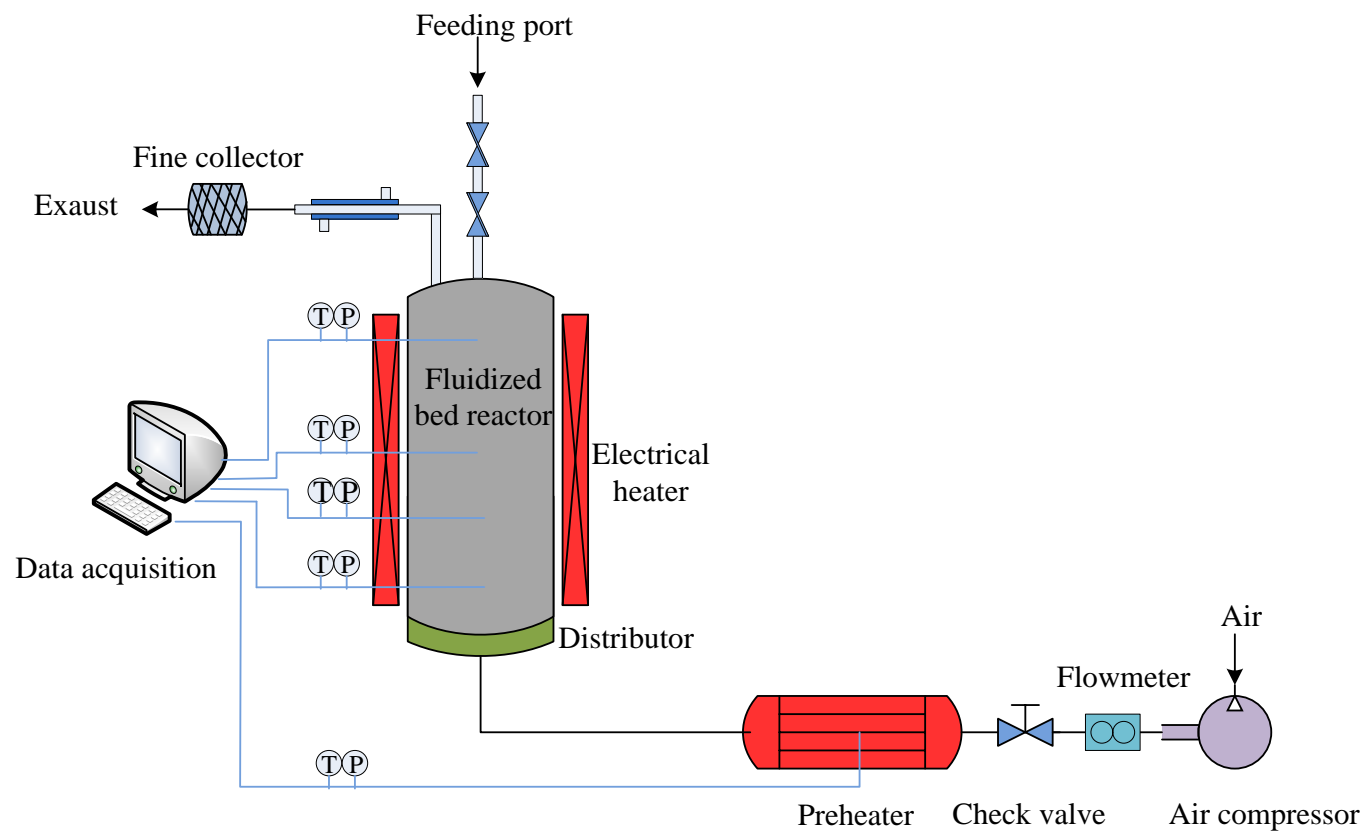

Figure 1. Sketch of experimental apparatus

Table 1. Elemental analysis mass percent of limestone sample

\begin{tabular}{cccc}
\hline Element type & Mass fraction (\%) & Element type & Mass fraction (\%) \\
\hline $\mathrm{Ca}$ & 42.7 & $\mathrm{O}$ & 43.8 \\
$\mathrm{Si}$ & 6.0 & $\mathrm{~K}$ & 1.1 \\
$\mathrm{Al}$ & 2.2 & $\mathrm{Sr}$ & 0.42 \\
$\mathrm{Fe}$ & 1.8 & $\mathrm{Ti}$ & 0.30 \\
$\mathrm{Mg}$ & 1.5 & $\mathrm{~S}$ & 0.18
\end{tabular}

For the $\mathrm{i}^{\text {th }}$ particle size distribution range, the mass fraction $\mathrm{P}_{\mathrm{i}}$ is defined as,

$P_{i}=\frac{M_{i}}{M_{0}}$

Where, $M_{0}$ is the initial mass of limestone particles and $M_{i}$ is the mass of limestone particles with the $i^{\text {th }}$ size distribution range. So that cumulative mass fraction is $P_{t}$ defined as

$\mathrm{P}_{\mathrm{t}}=\sum \mathrm{P}_{\mathrm{i}}$

The loss of fines $(<40 \mu \mathrm{m}) \Delta \mathrm{M}$ is defined as

$\Delta \mathrm{M}=\mathrm{M}_{0}-\mathrm{M}_{\mathrm{a}}$

Where, $M_{a}$ is mass of particles which are collected after attrition test.

The mass fraction of fines $P_{f}$ is 
$P_{f}=\frac{\Delta M}{M_{0}}$

The cumulative mass fraction of fines is noted as $R$ which is defined as

$R=\sum_{i=1}^{n} P_{f}^{i}$

Where, $P_{f}^{i}$ is mass fraction of fines after ith attrition test.

The mass fraction of particles which no longer maintain initial size after fragmentation with size decaying is denoted as decay rate $D_{m}$, defined as

$D_{m}=\frac{M_{0}-M_{\text {ini }}}{M_{0}}$

Where, $M_{i n i}$ is the mass fraction of particles which maintain initial size after attrition test.

\section{Results and discussions}

\subsection{Effect of initial particle sizes}

The attrition characteristic of four samples with particle size 300 450 $\mu \mathrm{m}, 450 \sim 600 \mu \mathrm{m}, 600 \sim 1000 \mu \mathrm{m}$ and $1000 \sim 1250 \mu \mathrm{m}$ were investigated at $25^{\circ} \mathrm{C}$ with fluidized velocity $0.68 \mathrm{~m} \mathrm{~s}^{-1}$. Fig. 2 shows the cumulative limestone particle size distributions for different initial sizes. Mass fractions of particles size range $\sim 100 \mu \mathrm{m}$ and fines decrease with increasing initial particle size.

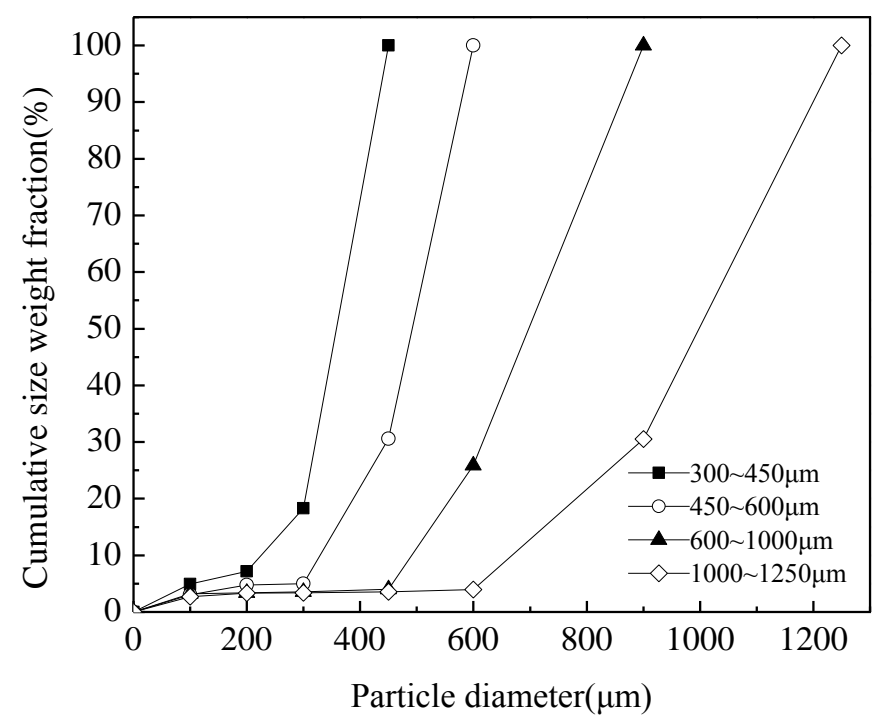

Figure 2. Limestone cumulative particle size distribution with different initial size after 1 hour's attrition (fluidized velocity of $0.68 \mathrm{~m} \mathrm{~s}^{-1}$ at room temperature) 
As it is shown in Table 2, particles with initial size of $300 \sim 450 \mu \mathrm{m}$ produce most fines. This is mainly because small particles have larger specific area and suffer much more abrasion than large ones. Surface abrasion is the dominant and notable attrition. Most of the particles in $\sim 100 \mu \mathrm{m}$ are produced by surface shearing of limestone impact.

Table 2. Fines weight of samples with different initial sizes limestone after attrition

\begin{tabular}{ccccc}
\hline Initial size $(\mu \mathrm{m})$ & $300 \sim 450$ & $450 \sim 600$ & $600 \sim 1000$ & $1000 \sim 1250$ \\
\hline$\Delta \mathrm{M} \mathrm{g}^{-1}$ & 3.6 & 2.5 & 2.1 & 1.9 \\
\hline
\end{tabular}

The decay rates of four samples are $18.3 \%, 30.6 \%, 26 \%$ and $30.5 \%$. This indicates that larger initial particles have higher dynamic energy and higher probability to crack when they impact inner walls and particles.

Particles decay into next size interval which is one level smaller than initial size. For example, $100 \mathrm{~g}$ particle with its initial size range $450 \sim 600 \mu \mathrm{m}$ was feed into the tube. After 1 hour attrition, $69.4 \mathrm{wt}$. \% of limestone maintains in size $450 \sim 600 \mu \mathrm{m}$, while particles produced by chipping in 300 450 $\mu \mathrm{m}$ accounts for $25.6 w t$. \%. The similar phenomenon of decaying into next size interval is found in other three samples.

\subsection{Effect of fluidized velocity}

The particle size distribution of two samples $(300 \sim 450 \mu \mathrm{m}, 450 \sim 600 \mu \mathrm{m})$ with fluidized velocity of $0.36 \sim 0.68$ $\mathrm{m} \mathrm{s}^{-1}$ are reported in Fig. 3 and Fig. 4.

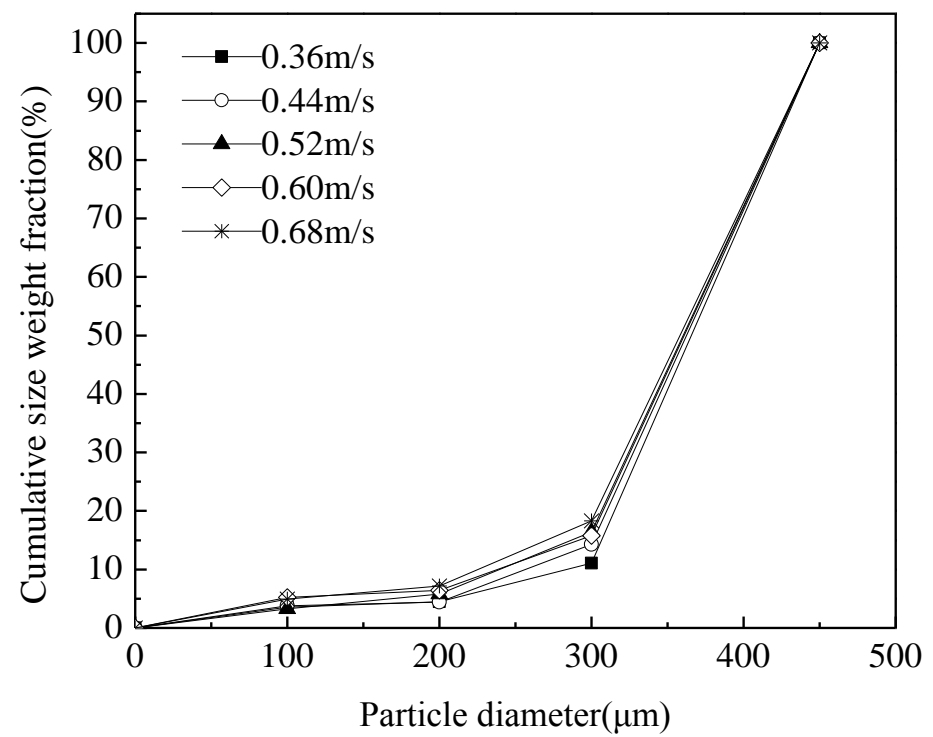

Figure 3. Limestone cumulative particle size distribution with different fluidized velocity after 1hour's attrition (initial size 300 450 $\mu \mathrm{m}$ at room temperature)

The curves shift to left as the fluidized velocity increases. This indicates that larger fluidized velocity enables particles to move faster, and particles crush each other with severe attrition. However, chipping and abrasion have different responses to the increasing fluidized velocity. At low fluidized velocity, abrasion is the dominant phenomenon. But at high fluidized velocity, chipping is playing leading role. As shown in Fig. 3, when fluidized velocity increases from $0.36 \mathrm{~m} \mathrm{~s}^{-1}$ to $0.68 \mathrm{~m} \mathrm{~s}^{-1}$, mass fraction of fines increases from $3.54 w t$. \% to $4.91 w t$. \% 
while mass fraction of $100^{\sim} 300 \mu \mathrm{m}$ increases from $7.56 \mathrm{wt}$. \% to $13.39 \mathrm{wt} . \%$. This is probably because more particles transform into high fluidized status and large particles easily shatter in a surface crack pattern when fluidized velocity increases. The minimum fluidization velocity of particles in $300 \sim 450 \mu \mathrm{m}$ is about $0.08 \sim 0.18$ $\mathrm{m} \mathrm{s}^{-1}$. The superficial gas velocity is 4 times of critical velocity which forms larger space among particles. This leads to more random impact instead of abrasion.

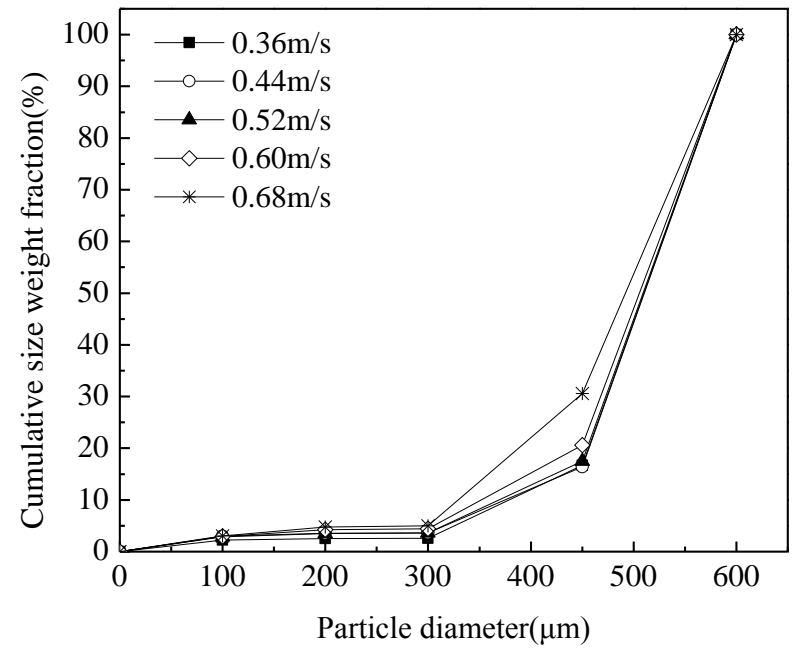

Figure 4. Limestone cumulative particle size distribution with different fluidized velocity after 1hour's attrition (initial size $450 \sim 600 \mu \mathrm{m}$ at room temperature)

As displayed in Fig. 4, samples in 450 600 $\mu \mathrm{m}$ have wider particle size distribution. Mass of particles size 200 $\mu \mathrm{m}$ produced by attrition almost doubles when fluidized velocity increases from $0.36 \mathrm{~m} \mathrm{~s}^{-1}$ to $0.68 \mathrm{~m} \mathrm{~s}^{-1}$. The similar results are obtained from other samples. When fluidized velocity exceeds $0.52 \mathrm{~m} \mathrm{~s}^{-1}$, mass fraction of produced particles in $300 \sim 450 \mu \mathrm{m}$ increases from $13.9 \mathrm{wt} . \%$ to $25.6 \mathrm{wt}$. \%.

\subsection{Relation of attrition and attrition time}

Sample of $450 \sim 600 \mu \mathrm{m}$ was tested for $0.5 \sim 8$ hours attrition. Curves in Figure 5 show attrition cumulative effect in size distribution. Results suggest that abrasion is the dominant attrition mechanism at first. In Figure 6 , surface peaks are chipped which produce grains and fines adhering to particles. Rounding off can be seen on particle surface for disappearance of many sharp points. In Figure 7, we can clearly see that after two hours attrition there are chipping produced.The shape change of particles suggests that more edges and corners are produced on surface. In Figure 5, the mass fraction of particles in $\sim 300 \mu \mathrm{m}$ increases evenly as time goes by while that of $300^{\sim} 450 \mu \mathrm{m}$ augments fast. It is because abrasion is the major attrition mechanism for particle size $\sim 300 \mu \mathrm{m}$ while chipping also contributes to attrition besides abrasion for particle size $300 \sim 450 \mu \mathrm{m}$.

After a period of attrition time, particles' shape, edges and sizes do not change obviously. Most of peaks and sharp edges disappear and sphericity of particles increases. After 1 hour attrition, $79.5 \mathrm{wt}$. \% of 450 600 $\mu \mathrm{m}$ particles keeps their initial size and this ratio drops to $73.8 \mathrm{wt}$. \% in 2 hours. After 4 hours attrition, $69.2 \mathrm{wt}$. $\%$ of $450 \sim 600 \mu \mathrm{m}$ remains in original size. At last $67.18 w t$. \% of total mass is in $450 \sim 600 \mu \mathrm{m}$. 


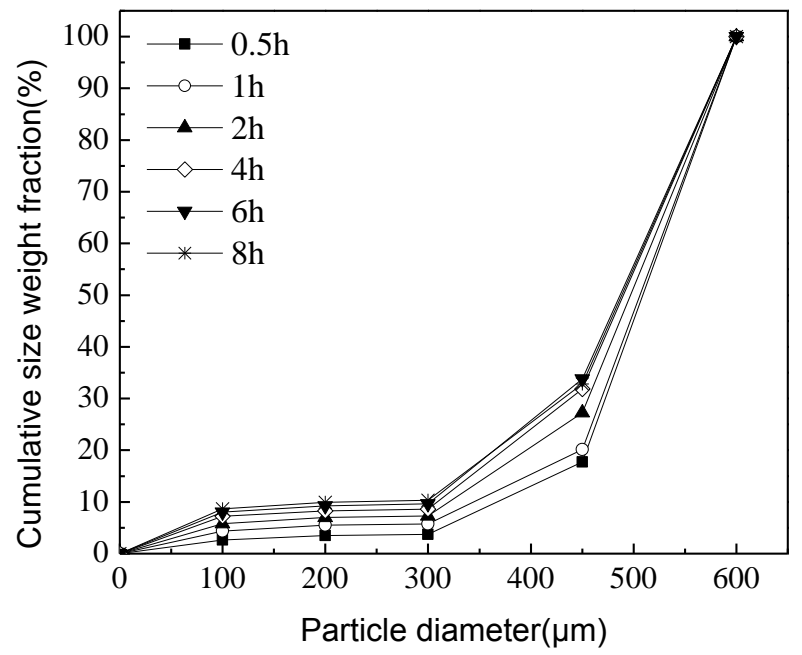

Figure 5. Limestone cumulative particle size distribution after different time attrition (initial size $450 \sim 600 \mu \mathrm{m}$ fluidized velocity of $0.68 \mathrm{~m} \mathrm{~s}^{-1}$ at room temperature)

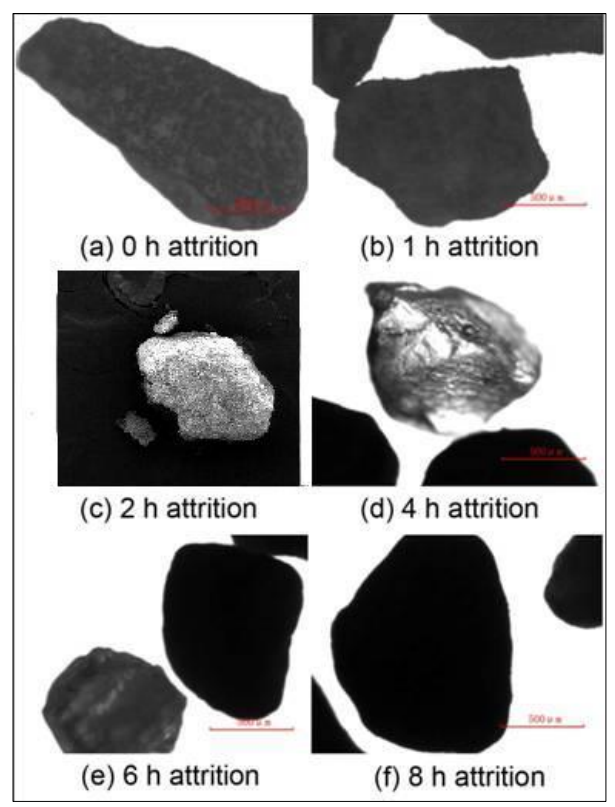

Figure 6. Photographs of limestone for $0 \sim 8 \mathrm{~h}$ attrition

Decaying rate of $0 \sim 4 \mathrm{~h}$ attrition is $7.5 \%$ per hour while the value for $4 \sim 8 \mathrm{~h}$ attrition is only $0.24 \%$ per hour. It means chipping is no longer in leading role, while abrasion becomes the major mechanism during $4 \sim 8 \mathrm{~h}$. After 2 hours attrition, cumulative mass fraction of fines $(R)$ reaches $5.79 \%$. 2 hours later, the slope of curve decreases. Only slight change of cumulative mass fraction of fines ( $7.25 \%$ to $8.68 \%)$ occurs during $4 \sim 8 \mathrm{~h}$. A fitting equation of cumulative mass fraction of fines $(R)$ to attrition time $(t)$ is obtained as

$$
R=-5.81 e^{-\frac{t}{6.98}}-4.73 e^{-\frac{t}{0.74}}+10.53
$$


Coefficient 6.98 and 0.74 are constants which have relation with inherent properties of limestone such as physical characteristic and chemical composition. Constant 10.53 is called initial attrition.

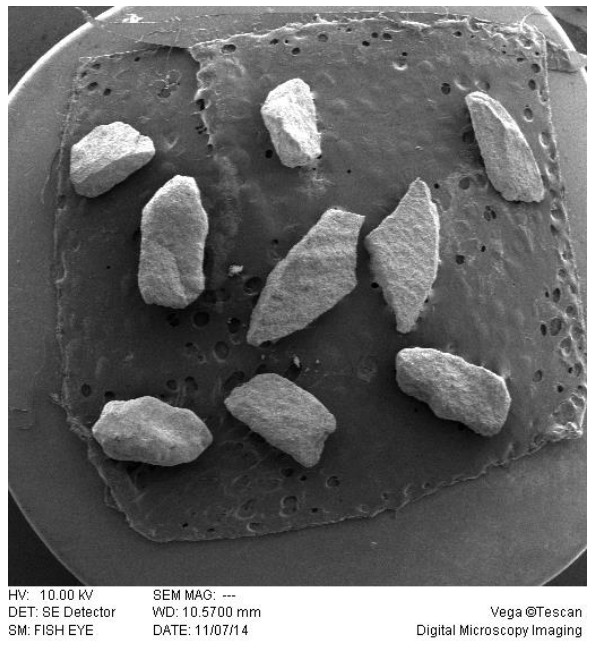

$\mathrm{O} \mathrm{h}$ attrition

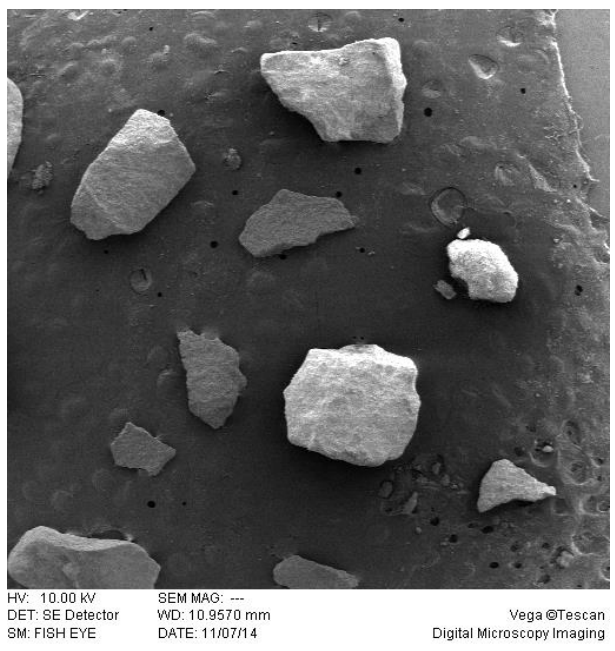

$2 \mathrm{~h}$ attrition

Figure 7. Photographs of limestone particles for attrition (initial size $450 \sim 600 \mu \mathrm{m}$ fluidized velocity of $0.68 \mathrm{~m} \mathrm{~s}^{-1}$ at room temperature)

\subsection{Effect of temperature}

The effect of temperature $\left(300^{\sim} 1000{ }^{\circ} \mathrm{C}\right.$ on attrition was studied with particle size $300 \sim 450 \mu \mathrm{m}$. Curve of mass fraction of 100 200 $\mu \mathrm{m}$ and $200 \sim 300 \mu \mathrm{m}$ particles after attrition are showed in Figure 8. During $300^{\sim} 750{ }^{\circ} \mathrm{C}$ mass fraction of 100 200 $\mu \mathrm{m}$ fluctuates slightly in $0.4 \% \sim 1.1 \%$. It increases after $750{ }^{\circ} \mathrm{C}$ and reaches $1.8 \%$ at $1000{ }^{\circ} \mathrm{C}$ Curve of mass fraction of $200 \sim 300 \mu \mathrm{m}$ has a similar trend as the decay rate of sample. It increases to $6.6 \%$ from 300 to $500{ }^{\circ} \mathrm{C}$ and decreases after $500{ }^{\circ} \mathrm{C}$. When temperature exceeds $750{ }^{\circ} \mathrm{C}$, it rises slowly and reaches $5.9 \%$ at $1000{ }^{\circ} \mathrm{C}$.

Table 3. BET tests of limestone particles after attrition at different temperatures

\begin{tabular}{cccc}
\hline $\begin{array}{c}\text { Temperature } \\
\left({ }^{\circ} \mathrm{C}\right)\end{array}$ & $\begin{array}{c}\text { Specific surface area } \\
\left(\mathrm{m}^{2} \mathrm{~g}^{-1}\right)\end{array}$ & $\begin{array}{c}\text { Specific volume } \\
\left(\mathrm{cm}^{3} \mathrm{~g}^{-1}\right)\end{array}$ & $\begin{array}{c}\text { Average size of pore } \\
(\AA)\end{array}$ \\
\hline 25 & 1.8188 & 0.002032 & 44.6958 \\
\hline 300 & 1.9866 & 0.002134 & 47.5805 \\
\hline 500 & 3.5834 & 0.006299 & 49.3425 \\
\hline 1000 & 5.1069 & 0.008978 & 70.3215 \\
\hline
\end{tabular}

Table 3 shows properties of particle surface. Surface appearance shows little change after $300^{\circ} \mathrm{C}$ attrition. As porosity increases, specific surface area augments. Limestone decomposes and releases $\mathrm{CO}_{2}$ at $500{ }^{\circ} \mathrm{C}$ forming gas pores. Specific volume of pore and specific surface area increases obviously over $500{ }^{\circ} \mathrm{C}$. Specific volume of pore increases 3 times and specific surface area increases 1.8 times at $1000{ }^{\circ} \mathrm{C}$ comparing with those at room temperature.

Based on related researches, $\mathrm{CaCO}_{3}$ begins to decompose at $500{ }^{\circ} \mathrm{C}$. Decomposition rate is maximum at $700^{\sim} 800^{\circ} \mathrm{C}$ and maintained steady at $810^{\circ} \mathrm{C}$. Similar conclusions were obtained in our tests. Contrary variation tendency are found between 500 and $700{ }^{\circ} \mathrm{C}$. Pictures which were taken by an electronic scanning microscope (VEGA $3 \mathrm{SBH}$ ) show conditions of particle surface after attrition. 


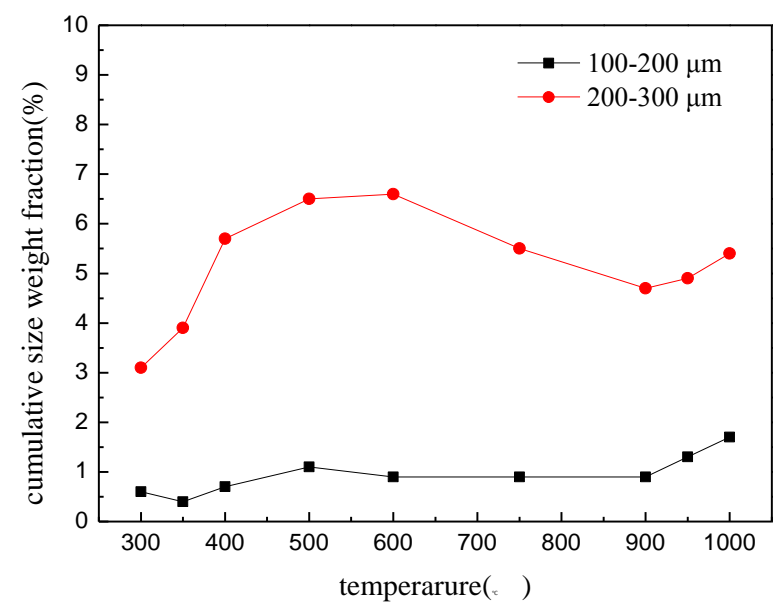

Figure 8. Curves of fractions for attrition limestones in 100 200 $\mu \mathrm{m}$ and $200 \sim 300 \mu \mathrm{m}$ with change of temperature at fluidized velocity of $0.36 \mathrm{~m} \mathrm{~s}^{-1}$

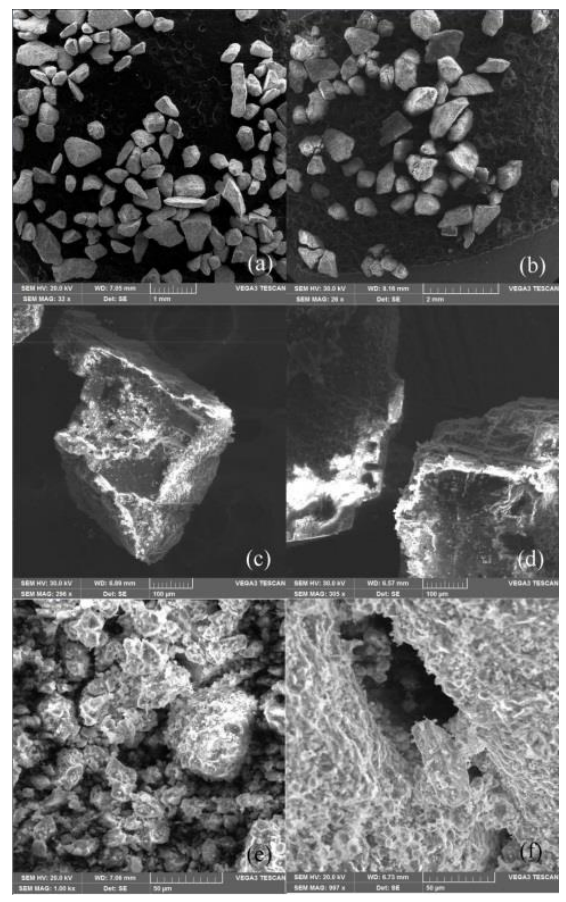

Figure 9. Photographs of limestone particles for attrition with change of temperature (a)sample before attrition; (b) (c) temperature $400{ }^{\circ} \mathrm{C}$, fluidized velocity $0.36 \mathrm{~m} \mathrm{~s}^{-1}$; (d) temperature $600{ }^{\circ} \mathrm{C}$, fluidized velocity $0.36 \mathrm{~m} \mathrm{~s}^{-1}$; (e) (f) temperature $750{ }^{\circ} \mathrm{C}$, fluidized velocity $0.36 \mathrm{~m} \mathrm{~s}^{-1}$; 


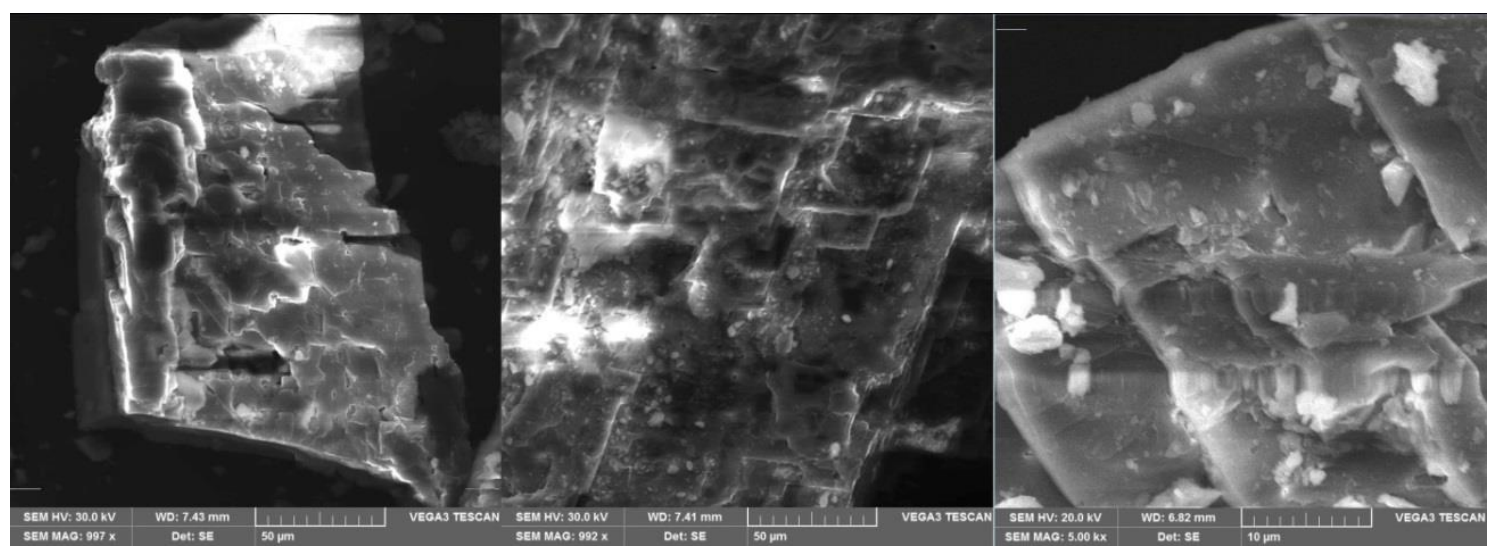

Figure 10. Photographs of limestone particles for attrition with change of temperature (stair-shaped surface)

By contrast in pictures (1000 5000 magnification) of particles tested at $750 \sim 1000{ }^{\circ} \mathrm{C}$, it is noticed that two different surface patterns are formed under chemical reaction. As shown in Figure 10, one is overlapping stairshaped surface. This pattern is flat and neat. Nearly no small granule can be found on surface. As shown in Figure 11, the other pattern is coarse texture-shaped surface. It is rough and attachable to granule. Its specific surface area is larger than that of stair-shaped surface. The reason of two formed patterns is that mixing ratios of $\mathrm{CaCO}_{3}$ and $\mathrm{CaO}$ are diverse after attrition. Decomposition degree of limestone calcination is different. Differences in thickness of $\mathrm{CaO}$ affect the micro-morphology of limestone.

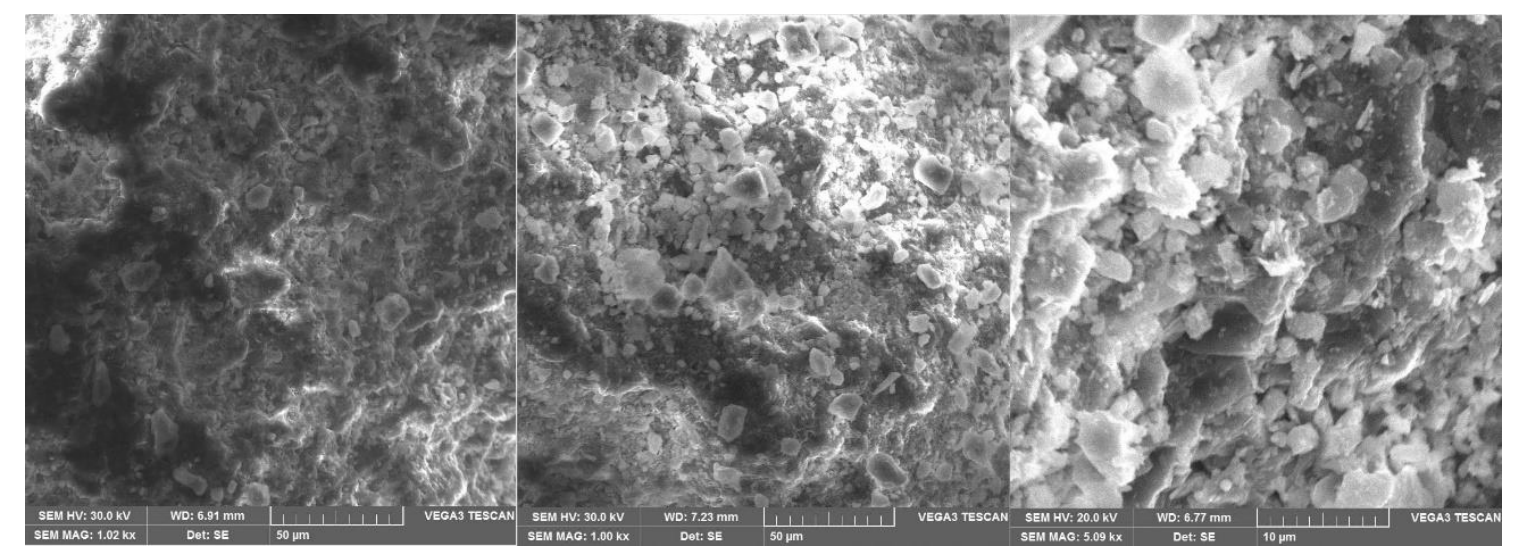

Figure 11. Photographs of limestone particles for attrition with change of temperature (texture-shaped surface)

It is remarkable that different surface pattern of particles have different meanings. During the process of carbonation in $\mathrm{CO}_{2}$ capture technology, $\mathrm{CaO}$ combines with $\mathrm{CO}_{2}$. Larger specific surface area promotes reaction rate and degree of carbonation. Besides, known from structure of particle surface, no matter what pattern is formed, pores which penetrate into core of particle can barely be found even in 5000 magnification. As shown in Figure 12, releasing of $\mathrm{CO}_{2}$ forms some hollows on particle surface. As calcination reacts, $\mathrm{CaCO}_{3}$ on surface decomposes and forms shell of $\mathrm{CaO}$. This shell enwraps unreacted $\mathrm{CaCO}_{3}$ and slows down the reaction rate of calcination. Surface attrition and chipping expose internal unreacted reactant. Obviously, chipping is more effective on this process. 


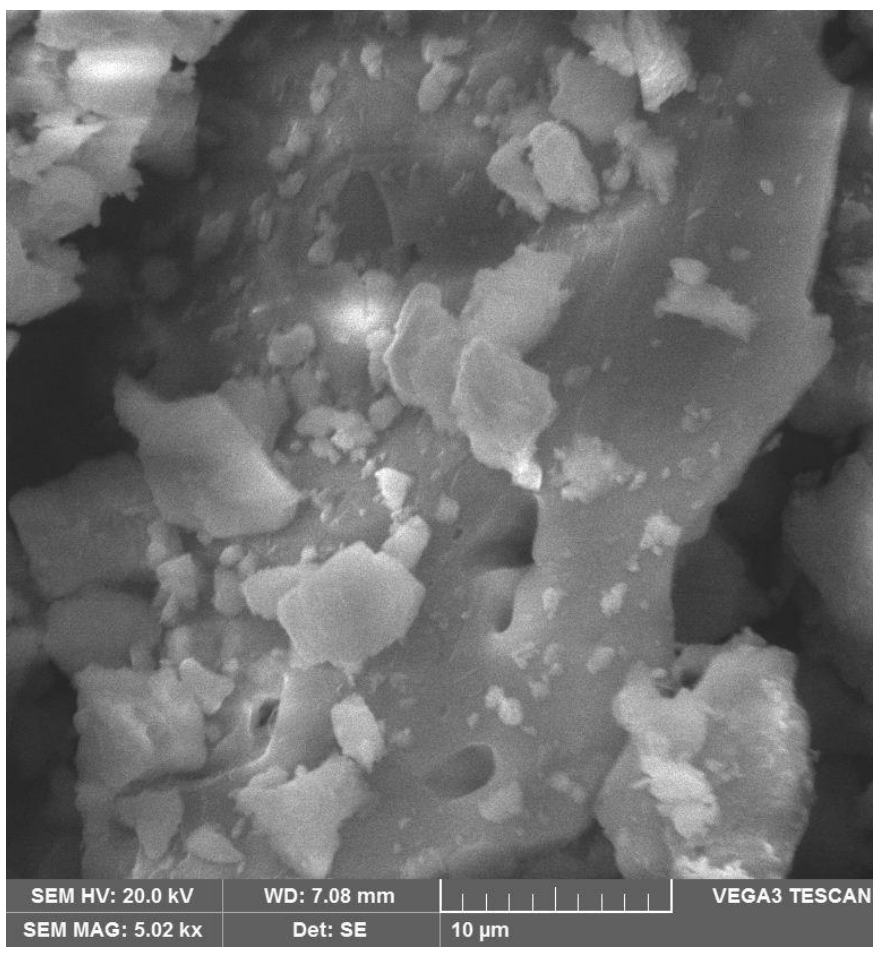

Figure 12. Photographs of limestone particles for attrition with change of temperature

\section{Conclusion}

Limestone particle attrition in a bench scale bubbling fluidized bed was investigated with fluidized velocity $0.36^{\sim} 0.68 \mathrm{~m} \mathrm{~s}^{-1}$ at $25^{\sim} 1000{ }^{\circ} \mathrm{C}$ and 1 atm pressure. The effects of initial particle sizes, fluidized velocity, time and temperature on attrition were studied. The dominant abrasion attrition is more notable when the initial size is smaller than $300 \mu \mathrm{m}$. For particles larger than $300 \mu \mathrm{m}$, chipping is the major attrition which produces wide size distribution. Two factors explain these two mechanisms. One is small initial size particles have more specific area suffering abrasion than large ones, and the other is large particles break easily when encountered same degree of impact. Chipping and abrasion have different responses to the increasing fluidized velocity. When fluidized velocity increases, chipping becomes more obvious due to higher dynamic energy and higher probability to crack. Meanwhile, when fluidized velocity exceeds the minimum fluidized of small particles, particles move so server that large space is produced among particles leading to more random impact instead of abrasion. Decaying rate of $0 \sim 4 \mathrm{~h}$ attrition is $7.5 \%$ per hour while $4 \sim 8 \mathrm{~h}$ has $0.24 \%$ per hour. 4 hours is a critical time to chipping in stability for this attrition system. The mathematical relation of cumulative mass fraction of fines $(R)$ to attrition time can be described with the fitting equation: $\mathrm{R}=-5.81 \mathrm{e}^{-\frac{\mathrm{t}}{6.98}}-4.73 \mathrm{e}^{-\frac{\mathrm{t}}{0.74}}+10.53$. As temperature increases from $300{ }^{\circ} \mathrm{C}$ to $500{ }^{\circ} \mathrm{C}$ and $750{ }^{\circ} \mathrm{C}$ to $1000{ }^{\circ} \mathrm{C}$, decay rate increases. During $500 \sim 700{ }^{\circ} \mathrm{C}$, decay rate decreases. Two different surface patterns (stair-shaped and texture-shaped) are formed under decomposition. Stair-shaped surface particles have larger specific area and higher reaction rate than texture-shaped ones. Chipping is an effective function for exposure of unreacted reactants.

\section{Acknowledgements}

The authors would like to say thanks for the financial support of the Natural Science Foundation of China with Project 
No. 51206200, the Fundamental Research Funds for the Central Universities with Project No. CDJZR12140031, and the Visiting Scholar Foundation of Key Laboratory of Low-grade Energy Utilization Technologies and Systems, MOE of China in Chongqing University (LLEUTS-201301).

\section{References}

Blamey J., Paterson N.P.M., Dugwell D.R. and Fennell P.S. (2010), Mechanism of particle breakage during reactivation of CaO-based sorbents for $\mathrm{CO}_{2}$ capture, Energy Fuels, 24, 4605-4616.

Chen Z., Grace J.R. and Lim C.J. (2011), Development of particle size distribution during limestone impact attrition, Powder Technology, 207, 55-64.

Chen Z.X, Lim C.J, Grace J.R. (2007), Study of Limestone Particle Impact Attrition, Chemical Engineering Science, 62, 867-877

Chen Z.X., Song HS, Portillo M., Lim C.J., Grace J.R. and Anthony E.J. (2009), Long-Term Calcination/Carbonation Cycling and Thermal Pretreatment for $\mathrm{CO}_{2}$ Capture by Limestone and Dolomite, Energy\& Fuels, 23, 1437-1444.

Chirone R., Massimilla L. and Salatino P. (1991), Comminution of Carbons in Fluidized Bed Combustion, Progress in Energy and Combustion Science, 17(4), 297-326.

Cook J.L., Khang S.J., Lee S.K. and Keener T.C. (1996), Attrition and Changes in Particle Size Distribution of Lime Sorbents in a Circulating Fluidized Bed Absorber, Powder Technology, 89, 1-8.

Coppola A., Montagnaro F., Salatino P. and Scala F. (2012), Attrition of limestone during fluidized bed calcium looping cycles for $\mathrm{CO}_{2}$ capture, Combust. Sci. Technol., 184, 929-941.

Coppola A., Scala F, Salatino P. and Montagnaro F. (2013), Fluidized bed calcium looping cycles for $\mathrm{CO}_{2}$ capture under oxy-firing calcination conditions: Part2. Assessment of dolomite vs. limestone, Chemical Engineering Journal, 231, 544-549.

Ghadiria M. and Zhang Z. (2002), Impact Attrition of Particulate Solids. Part 1: A Theoretical Model of Chipping, Chemical Engineering Science, 57, 3659-3669.

González B., Alonso M. and Abanades J.C. (2010), Sorbent attrition in a carbonation/calcination pilot plant for capturing $\mathrm{CO}_{2}$ from flue gases, Fuel, 89, 2918-2924.

Jia L., Hughes R., Lu D, Anthony E.J. and Lau I. (2007), Attrition of Calcining Limestones in Circulating Fluidized-Bed Systems, Industrial \& Engineering Chemistry Research, 46(15), 5199-5209.

Lee S.K., Jiang X.L., Keener T.C. and Khangr S.J. (1993), Attrition of Lime Sorbents during Fluidization in a Circulating Fluidized Bed Absorber, Industrial \& Engineering Chemistry Research, 32, 2758-2766.

Li Y.J., Sun R.Y., Liu H.L. and Lu C.M. (2011), Cyclic $\mathrm{CO}_{2}$ Capture Behavior of Limestone Modified with Pyroligneous Acid (PA) during Calcium Looping Cycles, Journal of Chemical \& Engineering, 50(17), 10222-10228.

Park Y.G. and Kim S.H. (2006), Desulfurization with a Modified Limestone Formulation in an Industrial CFBC Boiler, Energy Fuels, 20(1), 138-141.

Ray Y.C. and Jiang T.S. (1987), Particle attrition phenomena in a fluidized bed, Powder Technology, 49, 193-206.

Salman A.D., Hounslow M.J. and Verba A. (2002), Particle fragmentation in dilute phase pneumatic conveying, Powder Technology, 126, 109-115.

Scala F., Cammarota A., Chirone R. and Salatino P. (1997), Comminution of limestone during batch fluidized-bed calcination and sulfation, AIChE Journal, 43, 363-73.

Scala F., Salatino P., Boerefijn R. and Ghadiri M. (2000), Attrition of sorbents during fluidized bed calcination and sulphation, Powder Technology, 107, 153-167.

Xiao G., Grace J.R. and Lim C.J. (2011), Attrition characteristics and mechanisms for limestone particles in an air-jet apparatus, Powder Technology, 207,183-191.

Yang W.C., Werther J. and Reppenhagen J. (2003), Handbook of Fluidization and Fluid-Particle Systems, Marcel Dekker, Inc., New York, 209-245. 